\title{
Muslims by Ascription: On Post-Lutheran Secularity and Muslim Immigrants
}

\author{
David Thurfiell \\ Department for the Study of Religion, Södertörn University, \\ Stockholm, Sweden \\ david.thurfjell@sh.se \\ Erika Willander \\ Department of Sociology, Uppsala University, Uppsala, Sweden \\ erika.willander@soc.uu.se
}

\begin{abstract}
This article empirically explores the interplay between the secular, post-Lutheran majority culture and Muslim immigrants in Sweden. It presents the ambiguous role of religion in the country's mainstream discourse, the othering of religion that is characteristic to this, and the expectations of Muslims to be strongly religious that follows as its consequence. Four results of a web-panel survey with Swedes of Muslim and Christian family background are then presented: (1) Both groups largely distance themselves from their own religious heritage - the Muslims do this in a more definite way; (2) the Muslim respondents have more secular values and identities than the Christians; (3) contrary expectations, Christian respondents show more affinity to their religious heritage than the Muslims do to theirs; and (4) the fusion between the groups is prominent. The article concludes that equating religious family heritage with religious identity is precipitous in the case of Swedish Muslims.
\end{abstract}

\section{Keywords}

secular Muslims - cultural Christians - religious family background - Sweden state-church Lutheranism - migration 
Europe's demography is changing. With the migrant crisis of 2015 and the rise of immigration-critical parties in many countries, it is no exaggeration to say that the question of the status of non-European immigrants has become an issue that divides European societies and politics. Religious identity lies at the core of this debate because the demographic changes are also connected to a transformation of the religious landscape. A Christian and increasingly secular European situation is giving way to a multireligious population with a large and growing minority of Muslims.

In no country is this development more prominent than in Sweden. The Pew Research Center has made a prognosis for the 2050 demographics of Europe (in this case defined as the EU countries of 2016 plus Norway and Switzerland). According to their estimation, Sweden will be the country with the largest Muslim population in Europe, counted in percentage of the population. The Pew Research Center has divided their prognosis into three levels of immigration. Based on an estimation that Sweden's present (2016) Muslim population constitutes 8 percent of the population, ${ }^{1}$ the prognosis for the Muslim population of the country in 2050 ranges between 11 percent in a zeromigration scenario and 31 percent in a high-migration scenario. A mediumlevel scenario - which is the most probable - predicts 21 percent Muslims in the Swedish population of 2050, which would be the top score of all the 30 European countries included in the study (Pew 2017a).

This demographic development obviously entails a major change in the religious situation of Sweden. A large population carrying not only a religious identity but one that differs from the traditional Lutheran one obviously stands in stark contrast to the majority of Swedes, who view themselves as not being religious. In this article we want to empirically explore and discuss the dynamics between a post-Lutheran majority culture and a growing minority population with a Muslim family background. Starting from a presentation of the ambiguous role religion plays in the post-Lutheran majority discourse and the expectations that this discourse places on Muslim immigrants, the article moves on to address the empirical questions of how important religion actually is in the lives of Swedish Muslims and to what extent their stance on

1 This figure is based on the International Social Survey Programme (ISSP) survey of 20052008 and the specific question "What religion, if any, were you raised in?" to which "Muslim" was one of the possible response alternatives. In Sweden 2.6 percent (i.e., $3^{1}$ respondents out of 1,194) ticked "Muslim" in response to this question (ISSP 2008). The Pew Research Center adjusted this figure based on migration statistics, the strength of religious transmission between generations in different groups, and the fact that newly arrived immigrants have a non-response bias (Pew 2015: 225) and thus reached the figure of 8.1 percent Muslims in the Swedish population for 2016. 
religion differs from that of the majority. This article is an attempt at an empirically based analysis of the interplay between Sweden's now two biggest religious traditions: the nation-building Lutheranism of the former state church and the heterogenous Islam of immigrants and their children. It results in a call for the use of empirically based analytical categories when approaching the challenging domain of today's secularity and multireligiosity in Sweden.

\section{Swedish Secularization}

The far-reaching secularity of Sweden and its neighboring Nordic countries needs to be understood in the light of its history (Breemer et al. 2014; Joas 2014: 52-65; Gustafsson and Pettersson 2000). The birth of the Swedish nation in the 16th century was historically interwoven with the Protestant Reformation. For several centuries Swedish state administration, politics, and cultural life was heavily influenced by the dominance of the Evangelical Lutheran state church. In the former state church system, the church could be described as the administrative apparatus of the state. In the $17^{\text {th }}$, 18 th, 19 th, and, to some extent, 2oth centuries, the Church of Sweden - in addition to its obligation to preach and administer the sacraments - was responsible for the organization of health care, education, national registries, land surveying, the administration of justice, and many other functions. Based on the teachings of Luther's Small Catechism, the church provided the managerial, ideological, and ritual framework that held the Swedish realm and the lives of its people together. This means that membership in the church was the same as membership in the state, that baptism and communion were compulsory, that the population was questioned on their knowledge of Luther's teachings at house catechetical meetings, and that prayer meetings without the presence of a state-church representative were forbidden. To be Swedish during this period was defined as belonging to the same religion as the king (Willander 2020; Ekström 2003; Thurfell 2015).

Beginning in the early 19th century, the dominance of the church over societal administration slowly yet consistently started to dissolve. Through a number of regulations, reforms, and administrative restructurings, the dominance of the state church gave way to a secular order in society. Over a period of almost two hundred years, the church lost its religious monopoly and its dominion over the administration of justice, welfare services, health care, and education. The year 2000 marks the official divorce between church and state in Sweden and can be seen as a major change in a long process of legal secularization (Ekström 2003). 
An important aspect of this process has been the rhetorical construction of a secular self-understanding among Swedish people. Today, sociological surveys of religion confirm the image of Sweden as one of the world's most secular countries. In some surveys, as many as 72 percent of the Swedish respondents say that religion is not at all important in their lives (Pew 2018). As few as 15 percent answer positively to the question "Do you believe there is a personal God?" (Evs 2019), only 5 percent attend religious services during an average week (Willander 2019), and church membership rates are steadily decreasing. Hence, if you ask someone from Sweden if they are religious or not, they are likely to answer that they are not. Ronald Inglehart and Christian Welzel's famous "cultural map" (Inglehart and Norris 2003), in which the world's countries are positioned based on their populations' inclination toward selfexpression and secular rationality, confirms the position of the Swedes in the top-right corner of the map as the most secular people in the world.

More thorough analyses of the supposed exceptionality of Sweden's secularity have, however, nuanced these findings (Burén 2015; Willander 2020; Thurfjell 2015). As scholars of religion know, religion is an elusive category. It means different things in different settings, and it may also mean many things at the same time. Identifying oneself or another person as belonging to a religion can be a way of signaling ethnic identity, beliefs, or values (Rosen 2009). It can also be a way of signaling whether someone belongs to an in-group or an out-group (Willander 2020; Otterbeck 2010; Fitzgerald 2007). In societal situations where religion has become a politicized and delicate matter in particular, positioning oneself in relation to a religion or voicing an opinion about religion is most often something that signals a political stance (Hout and Fischer 2002; Putnam et al. 2010). This means that the answers that respondents give to survey questions may reflect their ideals and self-image rather than their actual practice (Brubaker 2013; Johansen and Spielhaus 2012). In addition to this, there is the social desirability factor, that is, that people tend to over-report doing things and holding views that are deemed socially desirable (Bader and Finke 2017).

Given these insights, we may revisit the alleged secularity of the Swedish majority population and seek to scrutinize what it is actually about. From what, we may ask, is it that 72 percent of Swedes distance themselves when they say that religion has no place in their everyday life?

As David Voas has pointed out, the growth of so-called nones (people ticking the box for "no religion" when asked what their religion is) in Europe may be explained in two different ways. The most intuitive explanation is perhaps that there has been a reduction in people's beliefs, practices, and affiliation. An alternative explanation, Voas points out, could however be that the general 
understanding of the meaning of the word religion has changed so that what before was recognized as an indication of religion no longer is. If that is the case, then, what actually is a steady level of practice and belief could be perceived by people as a decline (Voas 2019). Voas's reasoning is in line with a more general shift toward cultural sociological approaches in the study of religion (Edgell 2012).

It is likely that Swedish secularization can be described as a combination of a shift in practice and a semantic shift. The latter semantic aspect should not be forgotten. It moves the discussion about secularization away from a sole focus on beliefs, practices, and societal organization into the realm of language, rhetoric, discourse, and self-image.

Discourse analyses of how religion is constructed in Western societies have suggested that liberal societies make use of Islam as a counterimage in the construction of their own self-understanding. As a part of that process, liberalism is positioned as Islam's other (Martin 2010; Massad 2015; Sayyid 1997). If we revisit the case of Sweden and its population's far-reaching disinterest in religion with this perspective in mind, a slightly different image appears. This image is important for our analysis of the dynamics between the postLutheran majority and the growing Muslim population.

\section{The Paradox of Post-Lutheran Secularity}

If the secularity of the post-Lutheran Swedes is scrutinized with the possibility of a semantic shift in mind, we discover certain nuances that explain paradoxes in Sweden's far-reaching secularity.

Although as few as 10 percent answer positively to the European Values Study statement "There is a personal God" (Willander 2020), the survey results in regard to other questions of a similar nature give a significantly higher rate. If the word "personal" is dropped from the question, for instance, and the formulation is simply "Do you believe in God?" then the positive answers become 40 percent in 2016 (Willander 2019). If the vaguer options of the European Values Study's statements are considered, for example "there is some sort of spirit or life force," then 44 percent give a positive response. When added together, the Swedes who acknowledge having some kind of belief - whether it is explicit Christian theism or something more indistinct - amount to 54 percent of the population (Willander 2020). This sum, furthermore, appears to be stable and constant and shows no signs of diminishing (Willander 2014).

A second statistical example that contradicts the notion of Sweden's farreaching secularity concerns church attendance. It is evident that the church 
attendance rate of the Swedes is very low if compared internationally (Norris and Inglehart 2004). On average, about 1 percent of the population attends a Church of Sweden service on an average Sunday. This is admittedly a very low score, but, contrary to a widespread belief, it is not the result of a dramatic decline. As a matter of fact, statistical evidence suggests that the very low level of church attendance has been rather constant as far back as there are numbers to compare. The first serious attempts to count church attendance in Sweden were made in 1927. The results from that study suggest a church attendance level of about 5 percent (Gustafsson 2001; Willander 2019). Apparently, therefore, the church attendance rate has been steadily positioned on a few percent throughout the 2oth century.

As these two statistical examples show, the level of religiosity of the Swedes if defined as belief and practice - is not diminishing to the extent that the self-image of this group might suggest. In order to explain the perceived secularity of this population, something more than decreasing levels of measurable belief and religious practice therefore must be taken into account. We suggest that looking at some prominent features of the specific religious tradition that has dominated this country over the last couple of centuries, namely that of state-church Lutheranism, will help explain the situation. There are certain features in this religion that blur the borders of what is generally perceived as secular and that paves the way for the type of semantic shifts that appear to have taken place in Sweden.

First, the main core of Luther's theology - famously summarized in the three phrases sola fide, sola gratia, and sola scriptura - prescribes a Christian life in which merit has no role in the salvation of an individual. Instead, it is by grace alone - sola gratia - that a person is saved. Religious rituals - such as attending church - are thus transferred to the domain of worldly matters. They may be useful for upholding and organizing society and for bringing order and routine into people's everyday lives, but they have no part in the justification of sinners or in God's act of bringing believers to paradise. Relationships to the divine, by contrast, are moved into the domain of peoples' inner lives, and they become a matter of faith - sola fide - that is disconnected from ritual practices. Lutheranism also has nurtured the notion that Christians can fulfill their religious vocation in everyday life and in their "secular" professional lives, hence obliterating the border between worldly matters and religious calling (Gritsch 2010).

Another Lutheran idea that has been cultivated throughout history - especially in Lutheran state-church monarchies such as Sweden - is the so-called two kingdoms doctrine (Luther 1995). The core of this doctrine is that God rules not only through faith but also through the authority that he has instilled 
in worldly rulers. Hence, a good Lutheran should not oppose but yield to the worldly powers that be. These doctrinal features of Lutheranism make assessing the level of secularity in the religious behavior of Lutherans difficult. The reason for this is that if a Lutheran population - such as that of Sweden pays little attention to religious rituals, makes an effort to fulfill their worldly obligations, and shows loyalty to the system and the authorities, this could be construed as far-reaching secularity but also as far-reaching adherence to state-church Lutheran doctrine.

The confusion is not diminished by the fact that the version of state-church Lutheranism that has dominated the Church of Sweden - at least on the level of its clerical leadership - has been what may be labeled an "Enlightenment folkchurch theology" (Markkola 2015; Thurfell 2015). As David Sorkin has pointed out, European religion after the Enlightenment can be divided into the three currents of dogmatism, emotional revivalism, and Enlightenment theology. These three forms of religiosity find their expression in Protestantism as well as in Catholicism and Judaism from the 18th century onwards (Sorkin 2008). The Enlightenment theologies are characterized by an endeavor to combine Enlightenment ideals with religious traditions, an ambition to adjust doctrines to the findings of modern science, and an agreement with Enlightenment critique of politicized dogmatic religion. In Sweden, a prominent expression of Enlightenment theology in the 2oth century was the so-called Young Church Movement, a theological reform movement headed by a number of renowned clergymen who set out to redefine the identity of the Swedish state church. At the core of their program was the notion of the folk-church. The Young Church Movement can be described as a theological defense of a nationalist, broad, and inclusive church for all Swedes. As a defense against revivalist and High Church Christian movements that promoted a narrow and exclusive definition of what being Christian entailed, the Young Church leaders promoted the Lutheran understanding that all Swedes - regardless of their religious merit - should be embraced by the Church as included in the Christian flock. In line with Lutheran doctrine, they argued that the religious inclusion of an individual should not be dependent on the religious merit of that person but rather that it should reflect the pure grace of God, which asks nothing in return (Thidevall 2000).

The state-church Lutheran notion of the folk-church, as it was formulated in the early 2oth century, had a massive impact on the structure and self-understanding of the Church of Sweden. It constituted the theological foundation for the religion of the majority population in this country. To summarize, state-church Lutheranism in Sweden can be described, for most of its adherents, as a lifelong but exceptionally low-key relationship to the Church of 
Sweden that is brought to the fore in connection to rites of passage and certain holidays and which is vaguely related to certain beliefs and attitudes. It also contains - among the clerical elite as well as among most ordinary adherents liberal values, antiritualism, critique of hierarchies and dogmatism, and a connection to the Swedish national identity.

\subsection{The Post-Lutheran Concept of Religion}

Because of the low-key activity of its followers and its liberal ideas, liberal state-church Lutheranism is sometimes spoken of as something other than religion or as a particularly nonreligious type of religion. From the perspective of the study of religions, it is, however, reasonable to approach and analyze this version of Christianity as a religious tradition in its own right. It has its own history, its own doctrine, its own traditions and organizational structure, and its own connection to political power and local culture, just like most religious traditions do. In Swedish public discourse, however, the low-key religiosity of the state-church Lutheran majority is not spoken of as a religious position at all. Instead, the notion of religion or religiosity is, among this majority population, predominantly used as a description of other people. ${ }^{2}$ Pentecostals, Catholics, Muslims, and Hindus can easily be described by this word as may the members of various other religious minorities and sects, but it is not felt to be fitting for one's own group.

One way to describe the discourse about religion among the state-church Lutheran majority is therefore to speak of an "othering" of religion. Religion, in this mainstream Swedish discourse, is: (1) something that others have; (2) something that often is extreme and potentially destructive; (3) something that in one's own group existed in the past; and (4) something that is characterized by intense engagement, affinity, belief, and practice. All these characteristics form a contrast to the self-perceived secularity of the mainstream (Thurfell 2015; Willander 2013, 2014.).

There are multifaceted historical explanations for the severing of the link between state-church Lutheranism and the general notion of religion in the Swedish language. In addition to the decline of the state-church institutions, the general shift toward compartmentalization in modern society, the promotion of a modernist self-image by the political establishment, and the growing presence of maximalist revivalist Christians in the public debate all contributed to this development. In Sweden's modern history, however, the situation

2 This has been shown in regard to media by Lövheim 2004 and Willander 2014, in school by Kittelmann Flensner 2015 and Aldrin 2018, and in general by Thurfell 2015. The observation has also been confirmed by studies of the Muslim minority; see Otterbeck 2015. 
culminated in a large-scale cultural debate that took place in the 1950s and that is referred to as the "the believing and knowing debate" (tro och vetandedebatten) (Lundborg 2002; Thalén 1994). In this debate, which took place in the mass media, a secular humanist and atheist philosopher by the name of Ingemar Hedenius launched a full-scale attack on religious beliefs in general and the clerical establishment of the Church of Sweden in particular. He accused them of being superstitious, immoral, unscientific, and deceitful. The bishops and theologians of the church - trained in the tradition of folk-church Enlightenment theology - failed to defend their positions in a way that was intelligible to the educated public. Arguably, this conflict brought forth a situation in which the old state church, including its clerical establishment, lost its prerogative of interpretation concerning the meaning of concepts such as faith, belief, and Christianity in the Swedish language. This resulted in the idea of what it meant to be $a$ Christian getting severed from the broad inclusive and nationalist understanding of the Lutheran state church (Thurfjell 2015).

As a consequence, the rather peculiar religious situation that is characteristic of the Swedish mainstream population emerged. In this context, then, it is commonplace to be baptized, confirmed, and married in the church, to have a biblical name, to bury one's loved ones in the church, to celebrate Christmas and Easter, to think and behave in ways informed by Lutheran tradition, to hold undogmatic religious beliefs that are in line with the current liberal, Enlightenment teachings of the clerical establishment, to be a member of the Lutheran church, and via the tax system pay an annual membership fee (a few hundred Euros per year) to this church. It is commonplace to do all of these things but still feel that it would be incorrect to label oneself $a$ Christian since it is felt that this label ought to be reserved for the more maximalist religiosity of others. ${ }^{3}$

This situation in the general discourse on religion among Swedish statechurch Lutherans also coincides with the measurements for religiosity found within the sociology of religion. If religion is defined, as is common in this field, as a combination of self-proclaimed affiliation, professed theistic beliefs, and regular practices (McAndrew and Voas 2011), then only some 5 percent of the Swedish majority will be found to be religious, since only a very few live up to these criteria. Our ambition here is not to argue that this is necessarily wrong. We only want to point out that this perceived nonreligiosity is in line with the teachings of the particular state-church Lutheran tradition and that this situation creates some rather confusing semantics in which secularity and

3 For instance, 62 percent of those who celebrate Easter strongly disagree with the notion that they are Christian. 
Lutheranism become, not each other's opposites, but two highly intertwined categories. The purported secularization of the Swedes, therefore, is in part a consequence of their religion.

\subsection{Enter the Muslims}

It is into this discursively confusing situation that Muslim immigrants come. With the exception of a few earlier cases, Muslim immigration to Sweden started in the 196os and 1970s with labor migration from Turkey and the former Yugoslavia. From the 1980s onwards, Muslims moving to Sweden have mostly been refugees and relatives of people already living in the country (Sorgenfrei 2018). Today, the five most common countries of origin among Swedish Muslims are Bosnia, Iran, Iraq, Syria, and Turkey (Statistics Sweden 2019).

In the public debate as well as in social-scientific research, it is common to speak of these immigrants as Muslims (Puranen 2019; Wadensjö and Tibajev, forthcoming; Yilmaz 2016). This means that they are defined by their religious family background rather than by other aspects of their identities. Given the understanding of religion that permeates Swedish majority discourse, this characterization of their identity entails an expectation that Muslims are more religious than the post-Lutheran majority whose connections to Christian practices are not thought of as religious at all. A relevant question, therefore, is whether or not this is the case. Are people with a Muslim family background more religious than those with a Christian one in Sweden? And to what extent is it reasonable to categorize immigrants in Sweden by their religion rather than in terms of their nationality, ethnicity, language, class, or gender? Cross-national research on religious socialization among Muslim immigrants in Europe shows a polarized tendency. While broad layers of first-generation immigrants maintain a cultural connection to their religious heritage, the second generation tends to either strengthen or weaken their affinity to Islam (Voas and Fleischmann 2012).

Whether or not it is reasonable to equate a Muslim family background with a Muslim identity is an empirical question. In addition to family background, therefore, the perceived importance of their religious identity should be taken into account when assessing the relevance of a religious categorization. There are surveys on how important religion is perceived to be in the lives of people in at least some of the countries of origin of Swedish Muslims. These surveys indicate vast differences between countries. In Bosnia, for instance, only 36 percent of the population deem religion to be important in their lives. The corresponding figure for Turkey is 67 percent whereas in Iraq it is as high as 82 percent (Pew 2017b). It should also be remembered that the modern political histories of Bosnia, Iran, Iraq, Syria, and Turkey have contained strong 
elements of secularism. The socialism of Yugoslav Titoism, the Ba'athism of Syria and Iraq, the nationalist laicité of Turkey under Mustafa Kemal, and Iran under the Pahlavi kings were all secular ideologies that heavily influenced the political landscape and the modern history of these countries.

The answer to the question of whether or not immigrants from these countries that have come to Sweden can rightly be defined by their religious identity is therefore not obvious. Given the othering of religion that permeates Swedish public discourse, there is a risk that their religious identity is erroneously overemphasized (Lindberg 2015; Lövheim 2019).

\section{Method and Materials}

In the cross-national surveys that have concerned religion in Europe, the number of Muslim respondents is usually too small for statistical comparisons to be made (Puranen 2019). For this reason, the study of European Muslims is a field in which researchers have been forced to find innovative sample strategies (Brekke et al. 2019; Johansen and Spielhaus 2012). In this study, we have conducted a survey using the Laboratory of Opinion Research (LORE) web panel; specifically, we used LORE's citizen panel. The citizen panel reaches 60,000 active participants and is Sweden's largest web panel. It started as a self-recruited web panel in conjunction with the general elections in Sweden in 2010 and was then complemented by additional participants selected by random sampling techniques in 2012 (LORE 2019). Due to the characteristics of the citizen panel, the design employed in this article is based on comparisons of three groups: Swedes of Muslim family background, of Christian family background, and of secular family background.

The groups were identified in three steps. First, all the active citizen panel participants were asked "What religions do you have in your family, now and in previous generations?" 4 To this question, the participants could tick one or more of the following options: Christianity, Islam, Judaism, Buddhism, Hinduism, no religion, and other religion. For the option "other religion," it was possible to give a written specification. A total of 845 active participants reported Islam as a religion in their family history. In our study, these participants form the group having a Muslim family background in the broadest sense of the word.

In a second step, a survey was posted for the participants of this group. For the sake of comparison, surveys were also sent to a sample of participants

4 In Swedish: Vilka religioner finns i din familj, nu och i tidigare generationer? 
answering "Christianity" and "no religion" to the aforementioned question. These comparative groups were selected based on similarities with the Muslim group regarding age, gender, and education. Among the participants defined as having a Muslim family background, a total of 704 chose to complete the survey (83 percent of the participants). In the group defined as having a Christian family background, a total of 737 replied ( 87 percent of the participants in that group). Note that it is possible that the participants have several religions in their family background.

The survey posed 30 questions pertaining to the participants' ideas and practices related to Christianity, Islam, and secularity. In order to describe their level of religious commitment, a total of eight aspects of religion were used:(1) self-proclaimed family background; (2) upbringing; (3) celebration of holidays; (4) declared values; (5) affinity with organizations; (6) participation in organized activities; (7) faith/worldview; and (8) observance of rules/lifestyle. In order to avoid the risk of imposing religious adherence and consistency on the participants, all of them - regardless of their own family background - were asked about these eight aspects of Christianity, Islam, and secularity.

\subsection{Defining Family Background}

Having collected the data, we narrowed the scope of our analysis by regrouping the participants of the survey as a whole into two major religious family background categories: those of Muslim family background and those of Christian family background. We then defined family background in a stricter sense. A person was now defined as having a Muslim family background if she or he reported having a Muslim mother, father, or grandparent. Correspondingly, a Christian family background was defined in the same way. This resulted in one group with a Muslim family background $(n=162)$ and one group with a Christian family background $(n=1136)$. Note that these figures differ from the initial sample of respondents. Whereas the first step taken to identify the religious family background of the panel participants was based on an indefinite number of generations and kin relationships, this third step implies a stricter definition of family background as it only counts those whose parent(s) and grandparent(s) adhere to the religion. When we, in the following, refer to "Muslim" or "Christian family background," the phrase is used in this stricter sense. For the sake of readability, we will simply denote these groups as the Christian and the Muslim group.

While 704 respondents had Islam in their family, only 23 percent of these $(n=162)$ had Muslim parents or grandparents. The number of respondents with a Christian parent or parents or one or more Christian grandparents is larger than the original sample $(n=1136)$. This shows that several of the 
respondents who report having a Muslim parent or parents or one or more Muslim grandparents also have a Christian parent or parents or one or more Christian grandparents and thus that the family background of many of the Muslim respondents is religiously mixed.

Even in a precise meaning of the term "family background," having a Muslim or Christian family background can represent different kinds of family relations in the data. The most common case, as shown in Table 1, is to have two parents sharing religious identity, 59 and 48 percent, respectively, belong to this category. A total of 24 and 40 percent, respectively, have one parent with the religion, and for 13 and 16 percent, respectively, the family heritage consists of having grandparents belonging to the religion in question. It is substantially more common to have a mixed religious family background among those who are of a Muslim heritage. This is not surprising given the fact that they belong to a minority in a multireligious society in which Christians form the majority. Finally, 34 percent of the Muslim respondents also report having a Christian family background, so explicitly stating their mixed religious heritage. This means that there is a certain overlap between the groups since some participants $(n=59)$ have both religions in their family background. It should be noted that having a Muslim family background is far from being a clear-cut categorization of people. Having a religious background can mean a number of different things.

\section{$4 \quad$ Results}

Let us thus move on to present the results of the survey. With the intention of describing the participants' subjective relationships to their religious heritage, we will begin by describing their declared religious identity and attitudes

TABLE 1 Muslim and Christian Family Relations

$\begin{array}{lll}\text { Family relations } & \begin{array}{l}\text { Muslim family background } \\ \text { (\% of participants, } \mathrm{n}=162)\end{array} & \begin{array}{l}\text { Christian family background } \\ (\% \text { of participants, } \mathrm{n}=1136)\end{array}\end{array}$

\begin{tabular}{lcc} 
Only grandparents & 13 & 16 \\
$\begin{array}{l}\text { One parent and } \\
\text { grandparents }\end{array}$ & 40 & 24 \\
$\begin{array}{l}\text { Two parents and } \\
\text { grandparents }\end{array}$ & 48 & 59 \\
\hline
\end{tabular}


regarding secularity. Note that "secularity" will be used as an analytical category derived from the participants' responses to questions that explicitly probe this dimension. We will then present the results from the questions probing the eight aspects of Christianity, Islam, and secularity. All analyses are descriptive in character and serve the purposes of empirically based theorizing.

\subsection{Subjective Religious Identity: Similar and Secular}

It should be noted that having a Muslim or a Christian identity may mean different things. These terms evoke a variety of symbolic meanings and may be a point of disagreement (Frisk 2019). It is likely that their connotations vary significantly between those who subjectively identify with them and those who do not. A comparison between participants with a Muslim family background and those with a Christian family background shows that the subjective acceptance of these respective identities follows similar patterns (see Figure 1). In the Muslim group, the most common answer to the question "Do you see yourself as a Muslim?" is "no." More than half ( 55 percent) do not call themselves Muslims and one out of four (25 percent) in the same group say that they neither accept nor dismiss a Muslim identity. The answer "yes" to the question "Do you see yourself as a Muslim?" is only chosen by 20 percent of the group having a Muslim family background. A large majority comprising 8 o percent of

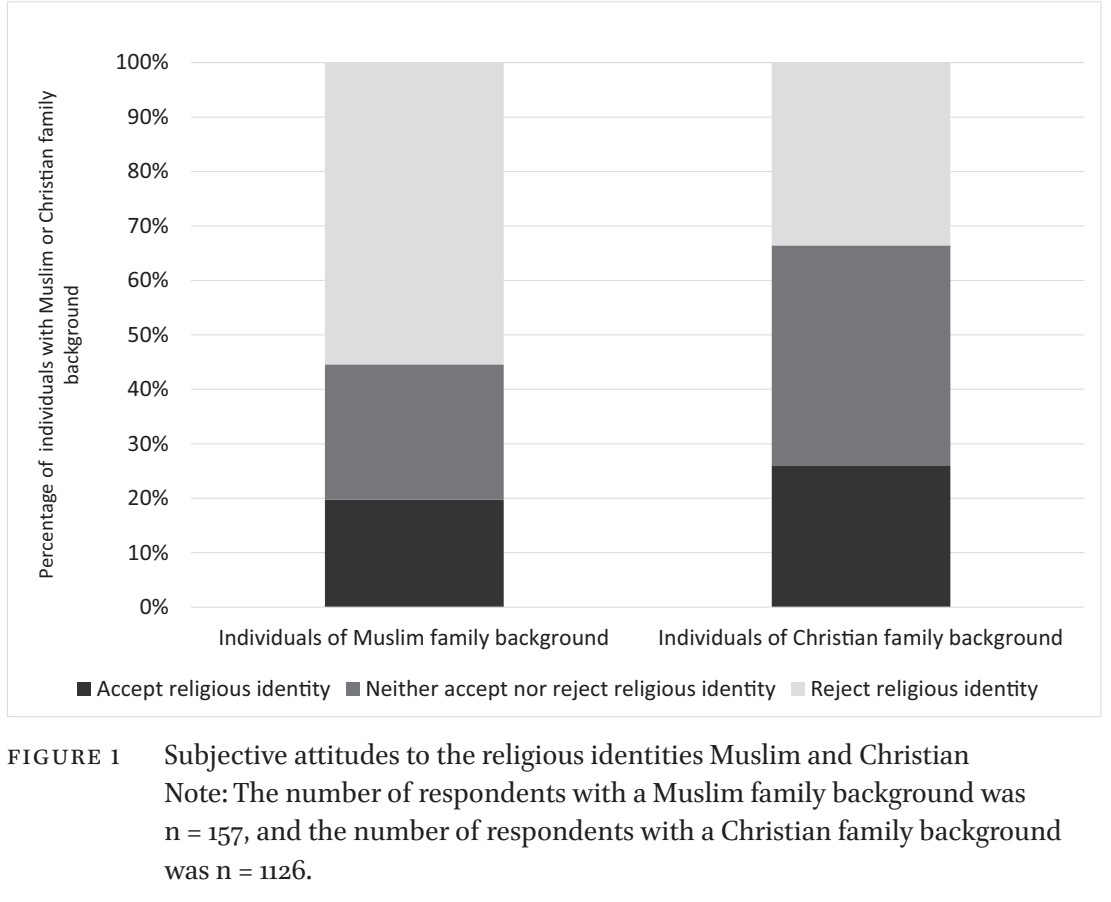


the group with a Muslim family background thus do not openly identify with a Muslim identity.

In the group with a Christian family background, the most common answer (40 percent) to the question "Do you see yourself as a Christian?" is that they "neither dismiss nor accept" a Christian identity. The second most popular option, then, is "no," which was chosen by 34 percent, and the least popular option is "yes," which was chosen by 26 percent.

In both the group having a Muslim family background and the group having a Christian family background, the answer that corresponds to accepting one's family religious background is the least popular. However, the option that corresponds to rejecting one's family religious background is more popular in the group comprising those with a Muslim family background compared with the Christian counterpart. Moreover, it is more common in the Muslim group to reject the family's religious identity than it is in the Christian group. Instead of rejecting the identity outright, the most popular choice for the Christian group is the "neither dismiss nor accept" option. The group with a Muslim family background, therefore, take a more active stance in relation to their religious heritage than the group with a Christian family background.

The image of those belonging to the Muslim group positioning themselves in relation to their family heritage and the majority culture's expectation is further strengthened by the replies to the question "Do you see yourself as secular?" (Figure 2). In regard to both groups, the most popular answer here is "yes" (68 percent of the Muslim group, 58 percent of the Christian group) followed by "no" ( 25 percent of the Muslim group, and 28 percent of the Christian group). Although both groups choose "yes" and "no" as their main options, the Muslim group is less indecisive than the Christian one. Only 8 percent of the Muslim group chose the option that signifies that they "neither dismiss nor accept" a secular identity. For the Christian group, the indecisive comprise 15 percent. Accordingly, even though both the Muslims and the Christians lean toward a secular self-identity, it is more common in the case of the Muslim group. The Muslims who do not profess a secular identity tend to explicitly reject it. In the Muslim group, attitudes toward a secular identity seem to have a polarizing tendency compared to the Christian group.

There is a statistical correlation between family background and subjective identity in our data: the stronger the Muslim or Christian family background, the higher the inclination to describe oneself as belonging to the respective religion. ${ }^{5}$ More surprising, however, is the fact that there is no statistical correlation between Muslim family background and self-proclaimed secularity.

5 The correlation between type of family background (only grandparents, one parent and grandparents, and both parents and grandparents) and subjective religious identity is 


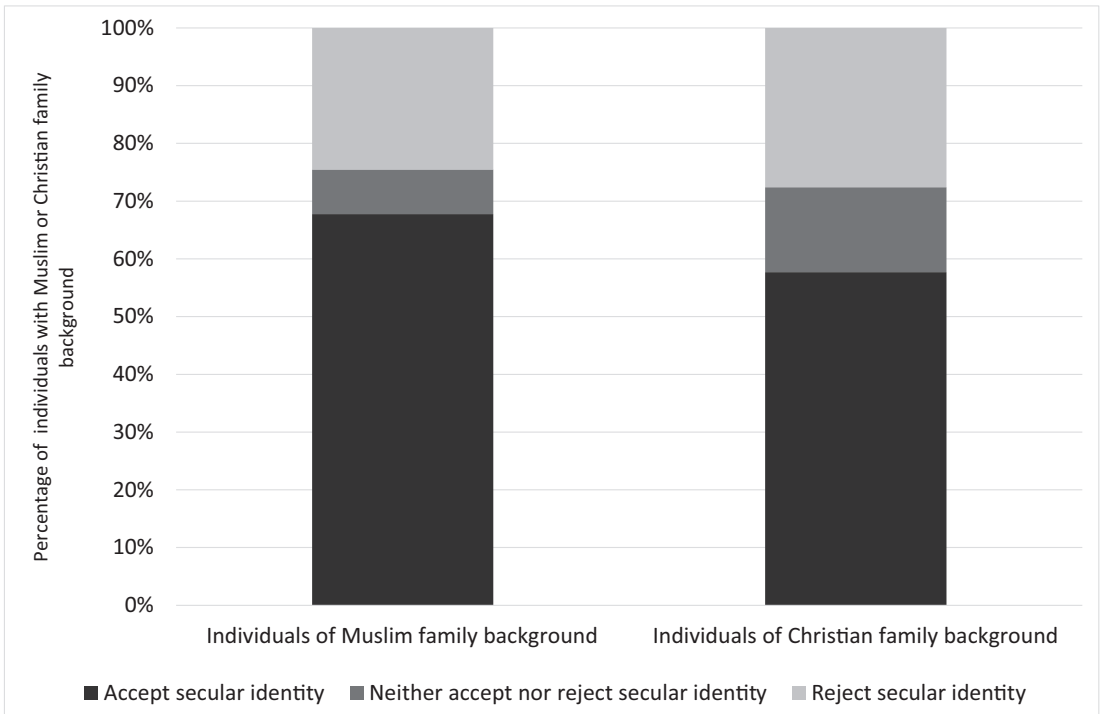

FIGURE 2 Subjective attitudes to a secular identity

Note: The number of respondents with a Muslim family background was $\mathrm{n}=155$, and the number of respondents with a Christian family background was $\mathrm{n}=1069$.

A strong Muslim family background, therefore, does not statistically correlate with either a weak or a strong secular self-identity. In this way, the Muslim group differs from the Christian group. ${ }^{6}$

Seen as a whole, this means that the two groups are far more likely to consider a secular identity than a religious one. Whether or not the Muslim group consider themselves as having a Muslim identity is dependent upon their religious family background. This cannot be said about those who identify with a secular identity, which is the most chosen option in the Muslim group. Here, family background seems to be less decisive. Instead, the social desirability of being secular in Swedish society may push people to self-describe as secular despite having a Muslim family background. Our findings here differ from the

positive and medium strong in the Muslim group $(\mathrm{r}=.47, \mathrm{n}=157, \mathrm{p}<.0005)$. In the Christian group, the correlation is positive, significant, yet less strong $(\mathrm{r}=.32, \mathrm{n}=1126, \mathrm{p}<.0005)$.

6 The correlation between type of family background and secular identity for the Muslim group is weak, slightly negative, and statistically insignificant $(\mathrm{r}=-.15, \mathrm{n}=155, \mathrm{p}=.061)$ whereas for the Christian group it is negative and statistically significant $(r=-.23, \mathrm{n}=1069, \mathrm{p}<.0005)$. The significant correlation for the Christian group should, nonetheless, be considered in the light of the larger sample size for this group, which influences measurements of statistical significance. 
results of previous research on Muslims in Sweden (Puranen 2019; Wadensjö and Tibajev 2020) and other countries (Koopmans 2015) which has suggested a stronger commitment to religion in this group.

\subsection{Agreement with Dimensions of Secularity: Muslims as Somewhat More Secular}

Let us move on to detailed views on aspects of secularity within the two groups. The Muslim group seems to hold positive attitudes toward certain aspects of secularity (see Figure 3 ). The group agrees with having secular values (69 percent), a secular lifestyle (67 percent), and a secular worldview (6o percent). If the response alternative "neither agree nor disagree" is added as a marker of uncertainty, the dimensions of secularity just mentioned apply to the vast majority of those with Muslim family background. For this reason, it is correct to say that the Muslim group has a positive attitude toward secular values and lifestyles.

As for the aspects of secular upbringing and self-proclaimed secular family background, the response alternative "agree" was chosen by a substantial proportion of our respondents. Forty-two percent of the Muslim group claims to have had a secular upbringing. In total, 38 percent claim to have had a secular family background. Moreover, 18 percent gave the response "neither agree nor disagree" to these questions. However, these aspects of secularity do not

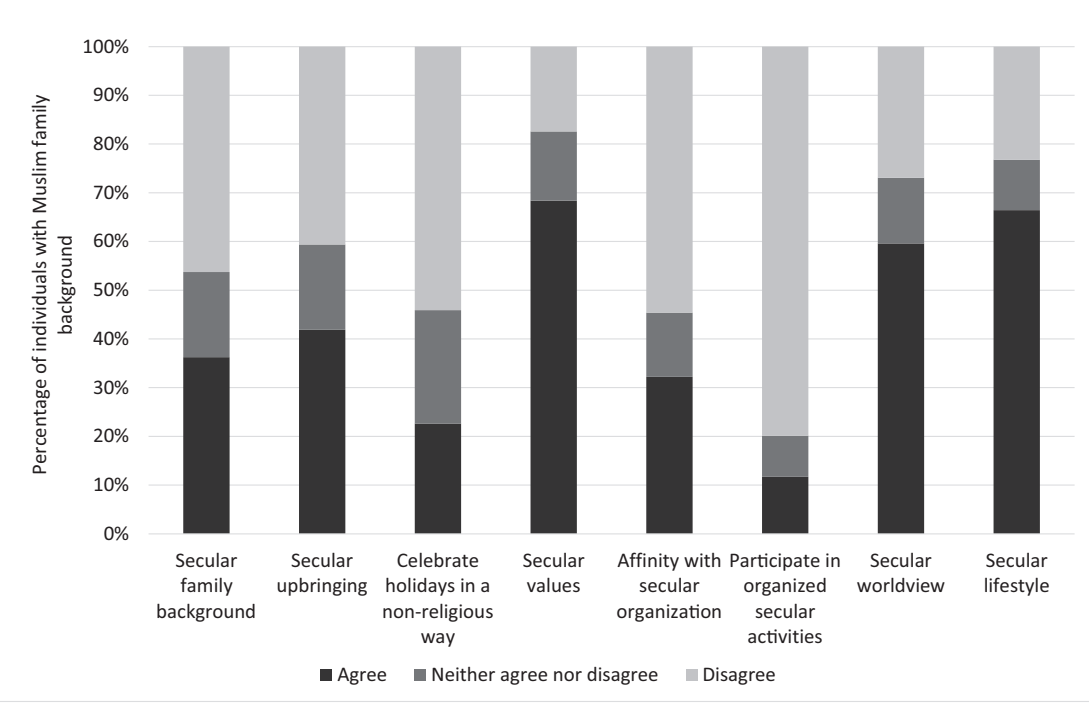

FIGURE 3 Attitudes toward dimensions of secularity among respondents with a Muslim family background $\left(\mathrm{n}=15^{2-160}\right)$ 
represent majorities in the way those concerning values and lifestyle do, but in light of our empirical definition of the Muslim group as those respondents who have a Muslim father, mother, or grandparent, the results are somewhat thought-provoking. Why, we ask ourselves, do four out of ten of those having a Muslim family background (according to these criteria) consider their background to be secular rather than Muslim?

In Figure 3, it is also visible that the group comprising those having a Muslim family background do not participate in organized secular practices to any great extent (only 12 percent), nor do they celebrate secular holidays (24 percent) or express any affinity with secular organizations (32 percent). These results may reflect a common factor, namely that there are no prominent secular organizations in Sweden that organize activities or initiate the celebration of certain holidays. The atheist association Humanisterna, for example, has about 5,000 members in a population of 10 million people (Humanisterna 2018). It may of course also be unclear to many respondents what secular practices and holidays denote.

Respondents with a Christian family background - that is, those who answered that their mother, father, or grandparents were or are Christian answer in ways that resemble the Muslim group's choices (Figure 4). The majority agree with the dimensions of secular values (6o percent agree), secular lifestyle ( 57 percent agree), and secular worldview (54 percent agree). These

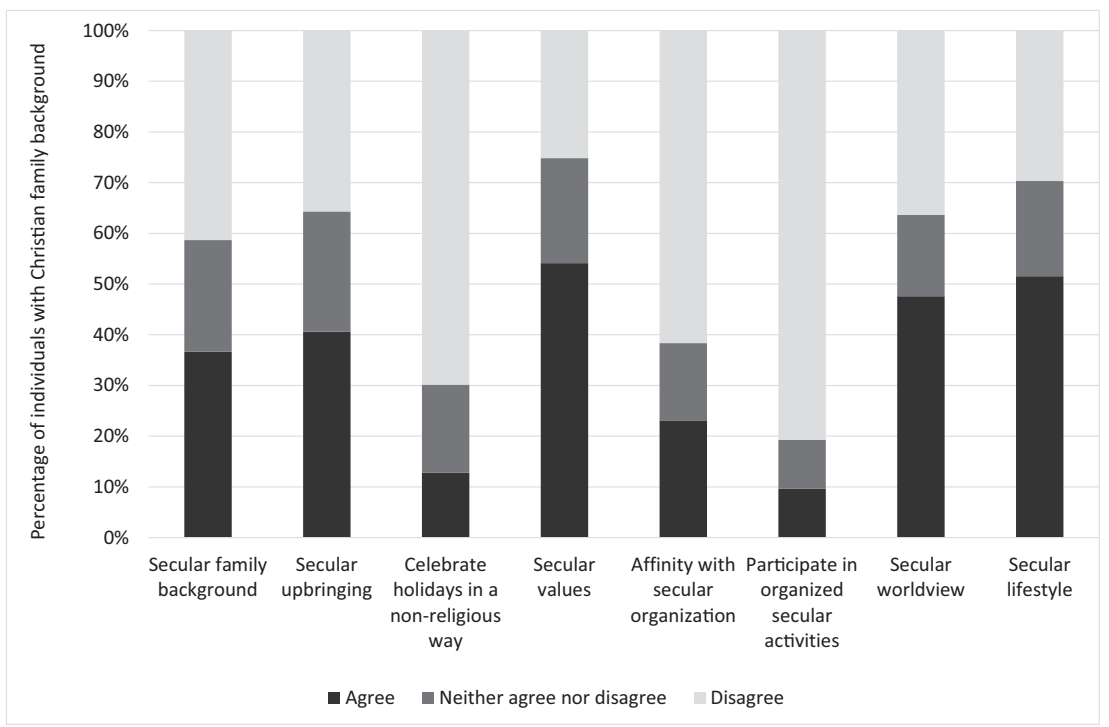

FIGURE 4 Attitudes toward dimensions of secularity among respondents with a Christian family background $(\mathrm{n}=1051-1110)$ 
shares are, however, lower than corresponding response patterns within the group comprising those with a Muslim family background.

By a similar token, the respondents with a Christian family background cautiously suggest that their background is, and upbringing was, secular. A total of 43 percent reports having had a secular upbringing while 39 percent describe their family background as secular. Adding these results to the results for the response alternative "neither agree nor disagree," those who tentatively lean toward the secular constitute majorities (secular upbringing equals 67 percent, and secular family background 62 percent). These totals are slightly lower than those of their Muslim counterparts because the proportion of the Christian group who answer that they neither agree nor disagree is larger.

Finally, few in the Christian group state that they participate in secular practices (10 percent agree), celebrate secular holidays (16 percent), or feel affinity to a secular organization ( 28 percent). These results may, as was the case with the Muslim responses, reflect the absence of organized secularity or uncertainty about what the formulation "secular practice and holidays" denotes.

Viewed as a whole, respondents with a Muslim family background and those with a Christian family background answer questions about secularity in similar ways. The Muslim group, however, is somewhat more assertive in their positive outlook on secularity and affirm to a slightly higher degree having secular values, lifestyle, and worldview.

\subsection{Agreement with Dimensions of Own Religious Heritage: Christians Show Greater Affinity}

We have asked the respondents to what extent they agree with various dimensions of Christianity and Islam. When the answers about dimensions of Islam among those who according to our criteria have a Muslim family background are studied (Figure 5), one can see that the only dimension to which the majority of the respondents give an affirmative answer is having such a Muslim family background (59 percent agree). Those who claim to have such a background do not necessarily answer affirmatively to having had a Muslim upbringing (only 26 percent agree).

Instead of affirming the dimensions of Islam, vast majorities of the respondents with a Muslim family background reject all dimensions of their inherited religion: by selecting "disagree," 91 percent indicate that they do not participate in organized religious practices, 86 percent that they do not feel any affinity with Muslim organizations, 83 percent that they do not follow the rules of Islam, and 80 percent, by selecting "disagree" signal that they do not identify with having a Muslim faith. These results stand in stark contrast to studies of people who affirm having a Muslim identity. Such studies show 


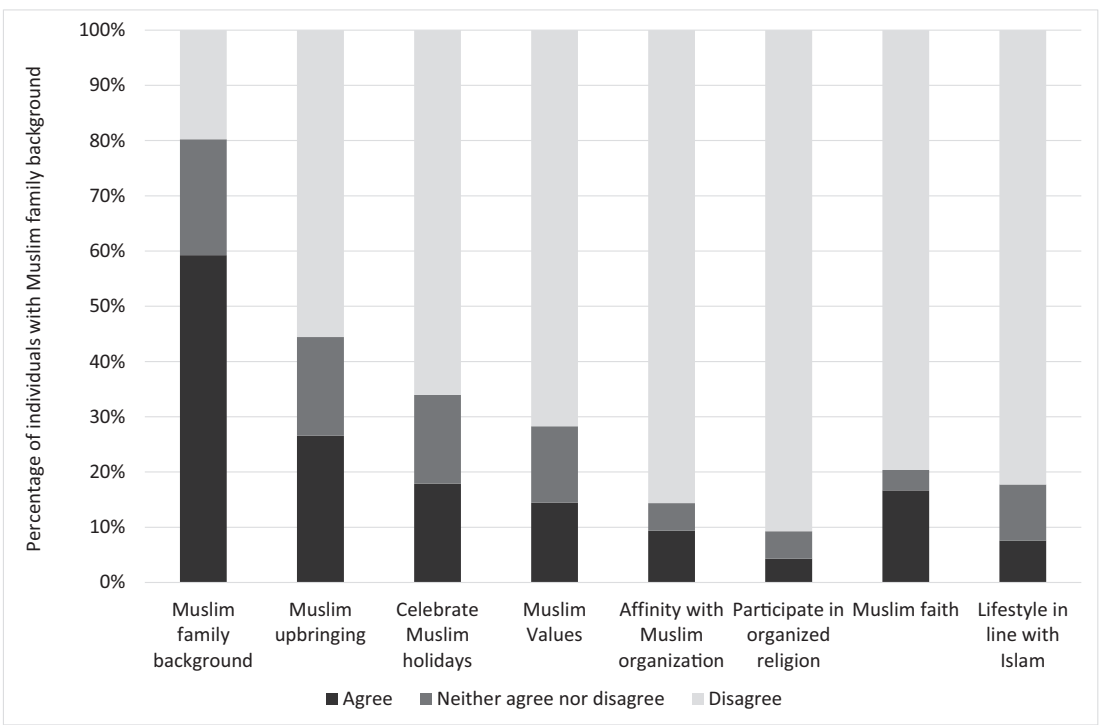

FIGURE 5 Attitudes toward dimensions of Islam among respondents with a Muslim family background $\left(\mathrm{n}=15^{2-162)}\right.$

that most who identify as Muslim answer that they also believe in and practice their religion (see, for instance, Willander 2019). Approaching the category of Muslim as a matter of family background, as we do, rather than as a matter of self-proclaimed identity, hence leads to very different results when it comes to the level of religious commitment. The category of Muslims, as understood here, comprises a far larger proportion of individuals who reject Islam. Answers to questions that concern the remaining dimensions of Islam (i.e., values and holidays) also indicate a certain tendency toward choosing the option "disagree." To be precise, 73 percent of the respondents having a Muslim family background disagree with having Muslim values, and 67 percent answer that they do not celebrate Muslim holidays. Hence, the overall pattern among people with a Muslim family background is to affirm several dimensions of secularity but reject most dimensions of Islam.

In the case of the group comprising those with a Christian family background, the response pattern relating to the dimensions of Christianity also diverges from the response pattern relating to secularity, although in a manner that differs from the Muslim group. The group with a Christian family background report celebrating Christian holidays ( 56 percent agree). Moreover, the response alternative "neither agree nor disagree" is more frequently chosen by those who make up the Christian group than the individuals belonging to the 


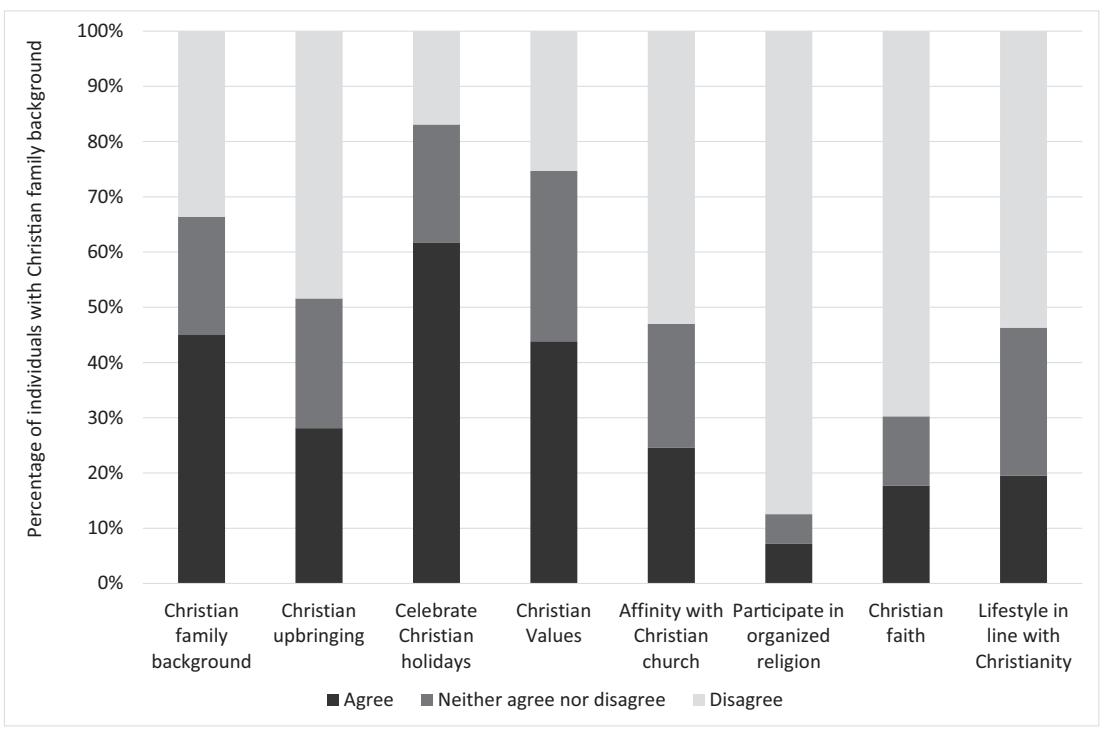

FIGURE 6 Attitudes toward dimensions of Christianity among respondents with a Christian family background $\left(\mathrm{n}=1095^{-1135}\right)$

Muslim group. This shows that the need to take a definitive stance in regard of religion is less strongly felt among the Christians. If responses belonging to the "neither agree nor disagree" category are considered, the Christian group leans toward a positive stance also in relation to the dimensions of values and background. In total, 70 percent agree tentatively to having Christian values, and 62 percent confirm, at least to some extent, having a Christian family background (Figure 6).

The tendency within the Christian group to be more positive toward Christianity than the Muslim group is to Islam becomes more visible if the proportion of those who choose the option "disagree" when responding to questions about the dimensions of Christianity is considered. Here, only the question about participation in organized religious practices gets a substantial majority (89 percent disagree). This result, nevertheless, is in line with statistics regarding church attendance in Sweden, which show that less than 5 percent of the population attend religious services on a regular basis (Thurfjell 2015; Willander 2014).

Therefore, we can conclude that respondents with a Christian family background show significantly more affinity with Christianity than those with a Muslim family background show in regard to Islam. 


\subsection{Far-reaching Community Fusion: Muslims Celebrate Christian Holidays}

Throughout our survey, we find that the Muslim and Christian groups are mixed. It is clear that religious identity is very far from being a clear-cut or easily definable denotation. As we have seen, this is true in regard to the matter of family background, but it is also the case if we look at other factors such as self-reported identity, values, and practice.

The most obvious mix can be found in the celebration of religious holidays. Here, we note that the proportion of respondents with a Muslim family background who celebrate traditional holidays is substantially smaller than is the case with the Christian group. Only 34 percent of the Muslim respondents celebrate Eid al-fitr, and 25 percent celebrate Eid al-adha. Among the Christians, 96 and 78 percent celebrate Christmas and Easter, respectively.

Moreover, among the Muslims, we find that a majority celebrate Christian holidays. As many as 84 percent of those with a Muslim family background celebrate Christmas, and 54 percent celebrate Easter. This means that the Muslims who participated in our survey celebrate Christian holidays to a greater extent than they celebrate Muslim ones. It is hardly surprising that the opposite is not the case; however, a total of 14 percent of the respondents with a Christian family background report having celebrated Eid al-fitr.

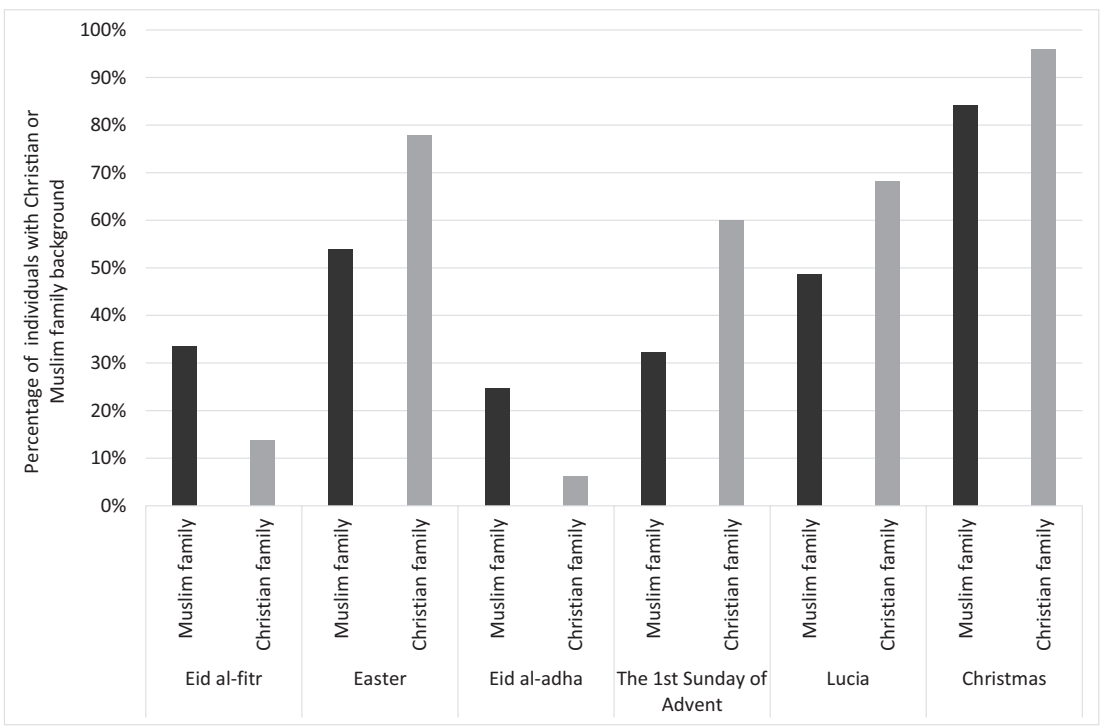

FIGURE 7 Celebration of religious holidays among respondents with a Muslim or a Christian family background

Note: The number of respondents with a Muslim family background was $n=158$, and the number of respondents with a Christian family background was $n=1131$. 
It should of course be noted that many respondents do not think of the seasonal holidays as an expression of religiosity. For instance, only 60 percent of those who celebrate Christmas answer affirmatively when asked if they celebrate Christian holidays, and only 28 percent of those who celebrate Eid say that they celebrate Muslim holidays. We conclude that people's holiday observances are shaped by the majority culture's seasonal practices regardless of their own family background and that holiday practices may be dependent upon variables other than religious affinity, and this is especially the case with people belonging to the Muslim minority. Figure 7 shows the level of observance of six major religious holidays by respondents having a Muslim or a Christian family background.

Our results suggest that Swedes with a Christian family background affirm certain aspects of that background. Although only a small minority of those respondents claim to participate in Christian practices or have a Christian faith, more substantial numbers claim to have Christian values, to celebrate Christian holidays, and to follow the rules of Christianity (see Figures 1 and 6). It therefore seems reasonable to say that a substantial number of Swedes can be defined as "cultural Christians," that is as people who do not have a religious Christian identity or belief but who still maintain an affinity with Christianity as a cultural heritage. When we set out to do this survey, we anticipated finding a similar group among the Swedes with a Muslim family background. This did not turn out to be the case. Instead, we have discovered that - as presented in Figure 5 - the vast majority of those having a Muslim family background have a weaker commitment to their religion in many ways. As shown in Figures 3 and 4, Muslims to a greater extent than Christians claim to have secular values, a secular worldview, and a secular lifestyle. It therefore seems reasonable to conclude that, while we find empirical justification for the notion of "cultural Christians" in our data, we cannot substantiate the notion of "cultural Muslims" in the same way. The notion of "secular Muslims" would be a more justifiable alternative based on our findings.

The category "Muslims," needless to say, is used in a number of different ways, and one may have different motives for choosing this categorization over others when describing people. There are a number of positions that may make it desirable to focus on the religious identity of a group of people as being Muslims. For example, as a theological category, "Muslim" denotes someone who submits to God. As a jurisprudential category in Islamic law, 
the distinction between Muslims and non-Muslims is important and has consequences for a number of legal and civil matters, and here the category of "Muslim" is usually used for anyone fathered by a Muslim man. From a sociological point of view, "Muslim" also functions as an ethnonym, and in political rhetoric it often works as a general category for those seeking to promote - or obstruct - the rights of this particular group (Mattes 2018). In public debates about Islam, it is common that these differing types of definitions merge in ways that suit the purposes of whoever is using them, hence creating a nebulous category with little empirical base.

From the point of view of the historical and social-scientific study of religion, none of these uses constitute a valid base for an academic analytical category. Scientific categories, arguably, should be distinct, transparent, and based on empirical evidence rather than on political or religious presumptions. Although categories will always be simplifications that can never perfectly match the empirical reality, they have to be sui generis in order to be valid. In other words, they have to reflect clusters of phenomena whose commonality exists not only in the eyes of the beholding scholar but which is also supported by observable criteria. We must therefore ask whether if in this case, as Samuli Shielke has eloquently put it, there is "too much Islam in the study of Muslims" (Schielke 2010).

Is there, we may ask ourselves, an empirical and social-scientific justification for categorizing people who have a Muslim family background as Muslim? There may of course be several other factors or features that are common among people belonging to this group. They may share specific experiences of migration, a common social situation, and similar linguistic or cultural features. These are factors that we have not looked into in this study. The question here is whether religion - here measured in terms of a self-reported identity, worldview, values, and practices - stands out as a common feature that is strong enough to make it the basis for an analytical category. Our conclusion is that it is not. Respondents with a Muslim family background do not see themselves as Muslims, they do not think of themselves as having a Muslim worldview or a Muslim lifestyle, nor do they report having Muslim values or practicing Islam. Furthermore, their lack of interest in Muslim congregational activities is striking. Even among those who celebrate Eid only a minority report celebrating "Muslim holidays."

Family background, in other words, does not say much about the level of self-reported religiosity in our dataset. A radical conclusion that can be drawn from our empirical findings could thus be to say that "Muslims," as an analytical category, is misleading. Consequently, demographic estimations, such as the one made by the Pew Research Center (2017a), would render substantially 
lower levels of Muslims in countries such as Sweden if religious identity was not equated with family background.

The results of our survey stand in stark contrast to the general perception of Sweden's Muslim minority among the post-Lutheran majority. Where most of the general public would expect people of a Christian heritage to be more secular than those having a Muslim background, our data show the opposite. In our data, "the Muslims" are less positive in regard to their religion and show considerably stronger affinity to secular values than their Christian compatriots. For many, these results are counterintuitive and the question of whether or not they reflect shortcomings in our collection of data therefore needs to be addressed.

It should be remembered that the web panel to which our questionnaire was sent consists of self-recruited respondents who volunteered to take part in this survey. Although we have no evidence to either substantiate or invalidate such a claim, there is a probability that having a secular identity correlates with a willingness to participate in a web panel designed to measure the population's political values in a country like Sweden. If that is the case, it is likely that the self-recruited respondents are more secularized than the average population of the country, and this would skew our results in a secular direction. However, it is puzzling that this only appears to make a significant difference in regard to the Muslim group since our findings show that people who have a Christian family background seem to accept their Christian heritage. This may be an indication of the stigmatization that is connected to a religious Muslim identity in Sweden.

If self-reported affiliation, belief, or practice are to be taken into consideration when deciding on the analytical categories through which we assess the strength of religiosity, the category of "Muslim" comes across as misleading when used to describe Swedes with a Muslim family background. Our data suggest that an empirically founded analytical category to describe this group of people would have to be based on something other than their religious heritage.

Our findings draw attention to some of the paradoxes that permeate the situation for immigrants and the children of immigrants having Muslim family backgrounds in a country such as Sweden. The post-Lutheran majority population maintains a cultural affinity to its Christian heritage but combines this with a secular self-understanding that includes a view of religion as something that others have. A consequence of this post-Lutheran majority position in Sweden is that Muslims, in their positions as an immigrant minority, are expected to be more religious than the self-defined seculars of the post-Lutheran majority. Our survey shows that this expectation cannot be empirically substantiated. 
The immigrants with a Muslim family background, our data indicate, are far from being as Muslim as the popular image of them suggests. Most of them neither believe in nor practice the religion of their heritage, and they do not retain a cultural affinity to it either. Perhaps, therefore, they should be described as "involuntary Muslims," or, more correctly, as "Muslims by ascription." They are being ascribed this religious belonging by the rhetoric of Muslim community leaders who seek the legitimacy that comes with having large numbers of followers, by politicians who are critical of Muslim immigration and - if we are not careful - by scholars of religion who elevate religious identity categorizations above other, more empirically valid ways, of denoting groups of people.

\section{References}

Aldrin, Viktor. 2018. Skolavslutningar i kyrkan och spelet om religion i svensk skola. Skellefteå: Artos.

Bader, Christoffer, and Roger Finke. 2017. "Evaluating Survey Measures Using the ARDA's Measurement Wizard." In Christoffer Bader and Roger Finke (eds.) Faithful Measures: New Methods in the Measurement of Religion, New York: New York University Press, 140-166.

Brekke, Torkel, Lene Kühle, Göran Larsson, and Tuomas Martikainen. 2019. "Mosques, Muslims, Methods: The Role of Mosques in Research about Muslims in Europe." Journal of Muslims in Europe 8(2): 216-233.

Breemer, Rosemarie, José Casanova, and Trygve Wyller (eds.). 2014. Secular and Sacred? The Scandinavian Case of Religion in Human Rights, Law and Public Space. Göttingen: Vandenhoeck \& Ruprecht.

Brubaker, Rogers. 2013. "Categories of Analysis and Categories of Practice: A Note on the Study of Muslims in European Countries of Immigration." Ethnic and Racial Studies 36(1): 1-8.

Burén, Ann af. 2015. Living Simultaneity: On Religion Among Semi-secular Swedes. Gothenburg: Gothenburg University.

Edgell, Penny. 2012. "A Cultural Sociology of Religion: New Directions." Annual Review of Sociology 38: 247-265.

Ekström, Sören. 2003. Makten över Svenska kyrkan: Om Svenska kyrkan, folket och staten. Stockholm: Verbum.

Evs. 2019. European Values Study 2017: Integrated Dataset (EVS 2017). GESIS Data Archive, Cologne. ZA75oo Data file Version 2.o.o, doi:10.4232/1.13314.

Fitzgerald, Timothy. 2007. Discourse on Civility and Barbarity: A Critical History of Religion and Related Categories. New York: Oxford University Press. 
Frisk, Emil. 2019. Med känsla för religion: Sentiment och innehåll i associationer till tre religiösa identiteter. Uppsala: Uppsala University.

Gritsch, Eric W. 2010. A History of Lutheranism. Minneapolis: Fortress Press.

Gustafsson, Göran. 2001. "Svenska kyrkan 1999 och 1927." In Margareta Skog (ed.), Det religiösa Sverige: Gudstjänst och andaktsliv under ett veckoslut kring millennieskiftet, Örebro: Libris, $73^{-104 .}$

Gustafsson, Göran, and Thorleif Pettersson. 200o. Folkkyrkor och religiös pluralismDen nordiska religiösa modellen. Stockholm: Verbum.

Hout, Michael, and Claude Fischer. 2002. "Why More Americans Have No Religious Preference: Politics and Generations." American Sociological Review 67(2): 165-19o.

Humanisterna. 2018. "Verksamhetsberättelse 2016-2017." URL: http://humanisterna .se/wp-content/uploads/2018/o4/Humanisterna-Kongresshandlingar-2018.pdf (accessed 27 April 2020).

Inglehart, Ronald, and Pippa Norris. 2003. Rising Tide: Gender Equality and Cultural Change Around the World. New York: Cambridge University Press.

ISSP. 2018. International Social Survey Programme: Religion III - ISSP 2008. GESIS Data Archive, Cologne. ZA495o Data file Version 2.3.o, doi:10.4232/1.13161.

Joas, Hans. 2014. Faith as an Option: Possible Futures for Christianity. Stanford: Stanford University Press.

Johansen, Birgitte, and Riem Spielhaus. 2012. "Counting Deviance: Revisiting a Decade's Production of Surveys Among Muslims in Western Europe." Journal of Muslims in Europe 1(1): 81-112.

Kittelmann Flensner, Karin. 2015. Religious Education in Contemporary Pluralistic Sweden. Gothenburg: Gothenburg University.

Koopmans, Ruud. 2015. "Religious Fundamentalism and Hostility Against Out-groups: A Comparison of Muslims and Christians in Western Europe." Journal of Ethnic and Migration Studies 41(1): 33-57.

Lindberg, Jonas. 2015. Religion in Nordic Politics as a Means to Societal Cohesion: An Empirical Study on Party Platforms and Parliamentary Debates 1988-2012. Uppsala: Uppsala University.

LORE. 2019. Citizen Panel for Researchers. URL: https://www.gu.se/en/som-institute/ the-swedish-citizen-panel/citizen-panel-for-researchers (accessed 12 November 2019).

Lövheim, Mia. 2004. Intersecting Identities: Young People, Religion and the Interaction on the Internet. Uppsala: Psychologia et sociologia religionum.

Lövheim, Mia. 2019. “The Swedish Condition': Representations of Religion in the Swedish Press 1988-2018." Temenos 55(2): 271-292.

Lövheim, Mia, and Jonas Bromander. 2012. Religion som resurs? Existentiella frågor och värderingar i unga svenskars liv. Stockholm: Verbum. 
Lundborg, Johan. 2002. När ateismen erövrade Sverige: Ingemar Hedenius och debatten kring tro och vetande. Nora: Nya Doxa.

Luther, Martin. 1995. Sermons of Martin Luther, the Church Postils, Vol. 4. Ada: Baker books.

Markkola, Pirjo. 2015. "The Long History of Lutheranism in Scandinavia: From State Religion to the People's Church." Perichoresis 13(2), 3-15.

Massad, Joseph. 2015. Islam in Liberalism. Chicago: University of Chicago Press.

Martin, Craig. 2010. Masking Hegemony: A Genealogy of Liberalism, Religion and the Private Sphere. London: Routledge.

Mattes, Astrid. 2018. "How Religion Came into Play: 'Muslim' as a Category of Practice in Immigrant Integration Debates." Religion, State and Society 46(3): 186-205. https://doi.org/10.108o/o9637494.2018.1474031.

McAndrew, Siobhan, and David Voas. 2011. "Measuring Religiosity Using Surveys: Survey Question Bank Topic Overview 4." Guildford: Survey Resources Network Question Bank, University of Surrey.

Norris, Pippa, and Ronald Inglehart. 2004. Sacred and Secular: Religion and Politics Worldwide. Cambridge: Cambridge University Press.

Otterbeck, Jonas. 2010. Samtidsislam: unga muslimer i Malmö och Köpenhamn. Stockholm: Carlsson.

Otterbeck, Jonas. 2015. “I Wouldn't Call them Muslims!': Constructing a Respectable Islam." Numen 62(2-3), 243-264.

Pew. 2015. "The Future of World Religions: Population, Growth Projections, 2010-2050." Washington, DC: Pew Research Center. URL: https://assets.pewresearch.org/wpcontent/uploads/sites/11/2015/03/PF_15.04.02_ProjectionsFullReport.pdf (accessed 12 November 2019).

Pew. 2017a. "Europe's Growing Muslim Population." Washington, DC: Pew Research Center. https://www.pewforum.org/2017/11/29/europes-growing-muslim-population/ (accessed 12 November 2019).

Pew. 2017b. "Muslims and Islam: Key Findings in the U.S. and Around the World." Washington, DC: Pew Research Center. URL: https://www.pewresearch.org/fact -tank/2017/o8/og/muslims-and-islam-key-findings-in-the-u-s-and-around-the -world/ (accessed 12 November 2019).

Pew. 2018. "Being Christian in Western Europe." Washington, DC: Pew Research Center. https://www.pewforum.org/2018/05/29/being-christian-in-western-europe/ (accessed 20 December 2019).

Puranen, Bi. 2019. Med migranternas röst: den subjektiva integrationen. Stockholm: Institutet för framtidsstudier.

Putnam, Robert, David Campbell, and Shaylyn Romney Garrett. 2010. American Grace: How Religion Divides and Unites Us. New York: Simon \& Schuster.

Rosen, Ina. 2009. I'm a Believer - But I'll be Damned if I'm Religious: Belief and Religion in the Greater Copenhagen Area: A Focus Group Study. Lund: Lund University. 
Sayyid, Bobby S. 1997. A Fundamental Fear: Eurocentrism and the Emergence of Islamism. London: Zed Books.

Schielke, Samuli. 2010. "Second Thoughts about the Anthropology of Islam, or How to Make Sense of Grand Schemes in Everyday Life." ZMO working papers 2: 1-16.

Sorgenfrei, Simon. 2018. Islam i Sverige: de första 1300 åren. Bromma: Myndigheten för stöd till trossamfund.

Sorkin, David. 2008. The Religious Enlightenment: Protestants, Jews, and Catholics from London to Vienna. Princeton: Princeton University Press.

Statistics Sweden. 2019. "Befolkningsutveckling - födda, döda, in- och utvandring samt giftermål och skilsmässor 1749-2018." Stockholm: Statistics Sweden. URL: https://www.scb.se/hitta-statistik/statistik-efter-amne/befolkning/befolkningenssammansattning/befolkningsstatistik/pong/tabell-och-diagram/helarsstatistik--riket/ befolkningsutveckling-fodda-doda-in--och-utvandring-gifta-skilda/ (accessed 12 December 2019).

Thalén, Peder. 1994. Den profana kulturens Gud: perspektiv på Ingemar Hedenius uppgörelse med den kristna traditionen. Uppsala: Uppsala University.

Thidevall, Sven. 200o. Kampen om folkkyrkan: ett folkkyrkligt reformprograms öden 1928-1932. Stockholm: Verbum.

Thurfjell, David. 2015. Det gudlösa folket: de postkristna svenskarna och religionen. Stockholm: Molin \& Sorgenfrei akademiska.

Voas, David. 2019. "Thinking about Religion in Numbers." Presentation at the Symposium Large datasets in the Study of religion at Uppsala University, 1 April.

Voas, David, and Fenella Fleischmann. 2012. "Islam Moves West: Religion Change in the First and Second Generations." Annual Review of Sociology 38, 525-545. DOI: https:// doi.org/10.1146/annurev-soc-071811-145455.

Wadensjö, Eskil, and Andrey Tibajev. Forthcoming. Religion och religiositet bland utlandsfödda.

Willander, Erika. 2013. “Jag tror på något': Konstruktioner av tro och tilltro." Sociologisk forskning $50(2), 117-138$.

Willander, Erika. 2014. What Counts as Religion in Sociology? The Problem of Religiosity in Sociological Methodology. Uppsala: Uppsala University.

Willander, Erika. 2019. The Religious Landscape of Sweden: Affinity, Affiliation and Diversity in the 21st Century. Stockholm: The Agency for State Support to Faith Communities in Sweden.

Willander, Erika. 2020. Unity, Division and the Religious Mainstream in Sweden. Palgrave Studies in Lived Religion and Societal Challenges. London: Palgrave Macmillan.

Yilmaz, Ferruh. 2016. How the Workers Became Muslims: Immigration, Culture, and Hegemonic Transformation in Europe. Michigan: University of Michigan Press. 